\title{
Sistem Informasi Simpan Pinjam Pada Credit Union (C.U) Ate Keleng Sibolangit
}

\author{
Ayu Melina Peranginangin ${ }^{1}$, Emerson P Malau ${ }^{2}$ \\ 1,2, Fakultas Ilmu Komputer Universitas Katolik Santo Thomas Medan, Indonesia
}

\begin{tabular}{|c|}
\hline ARTICLE INFORMATION \\
\hline $\begin{array}{l}\text { Received: April, 20, } 2021 \\
\text { Revised: April 22, } 2021 \\
\text { Available online: April,28,2021 }\end{array}$ \\
\hline KEYWORDS \\
\hline $\begin{array}{l}\text { CU, Simpan Pinjam, Nasabah, Visual Basic } \\
\text { 2010, Access. }\end{array}$ \\
\hline CORRESPONDENCE \\
\hline 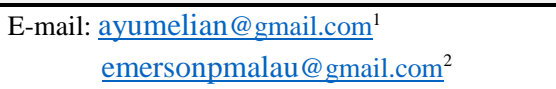 \\
\hline
\end{tabular}

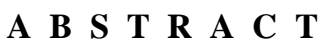

Computers provide the right solution in producing the most recent information. As is the case in every company, both state-owned and private companies have relatively many transactions, so a database is needed that can store and process the data efficiently, quickly and can be used whenever needed. C.U Ate Keleng Sibolangit is a private financial institution engaged in savings and loan services. The activities of C.U Ate Keleng Sibolangit are inseparable from customer savings and loan transactions, so a computerized system is needed so that transactions run well. This is what makes me want to overcome the weaknesses of the manual labor system that has been running so far. This software contains data on customers who will perform savings and loans. This software uses the Visual Basic 2010 programming language and Microsoft Access 2007 as a database.
\end{abstract}

\section{PENDAHULUAN}

Koperasi merupakan suatu organisasi atau badan usaha yang memiliki peranan sangat penting dalam menumbuhkan dan mengembangkan potensi ekonomi rakyat. Seiring dengan kemajuan zaman dan perkembangan teknologi informasi yang sangat pesat[1]. Credit Union (C.U) Ate Keleng Sibolangit adalah salah satu koperasi yang bekerja sama dengan yayasan Ate Keleng dan coordinator CU Partisipasi Pembangunan (Parpem) GBKP, serta ikatan pemersatuannya adalah desa sibolangit. Lembaga ini bergerak dalam bidang simpan pinjam dan dituntut harus mampu memberikan pelayanan yang bermutu bagi setiap anggotanya, terutama dalam pengolahan data dan penyediaan informasi yang dapat mendukung jalannya transaksi. Pada umumnya kegiatan Credit Union (C.U) Ate Keleng Sibolangit mengadakan transaksi simpan pinjam hanya setiap bulan atau setiap minggu ketiga saja. Banyaknya anggota dalam CU Ate Keleng Sibolangit yang harus dilayani perharinya dengan waktu transaksi yang ditetapkan yaitu 2 jam waktu peminjaman dan 2 jam waktu penyimpanan membuat setiap proses transaksi tidak efektif dan efisien dengan sistem yang ada sekarang.

Sebagai lembaga simpan pinjam, maka kegiatan utama yang dilakukan oleh CU Ate Keleng Sibolangit adalah menghimpun dana dari anggota dan menyalurkan kembali kepada anggota melalui bentuk pinjaman. Setiap anggota CU melakukan transaksi penyetoran maupun peminjaman sesuai dengan ketentuan yang berlaku di CU Ate Keleng Sibolangit.

Dengan jumlah anggota yang terus bertambah dan tersebar maka diperlukan cara yang dapat mempermudah proses transaksi yang dilakukan oleh anggota, terutama dalam transaksi penyetoran, peminjaman, dan penarikan simpanan maupun pinjaman[2], [3]. Untuk meningkatkan pelayanan pada masyarakat di bidang simpan pinjam, maka koperasi “Ate Keleng Sibolangit" perlu peningkatan pelayanan yang memadai. Fasilitas pelayanan yang ada, merupakan salah satu hal yang penting dalam memenuhi permintaan pelayanan bagi lapisan masyarakat mana saja, dengan mutu pelayanan yang baik. Dengan ditingkatkannya pelayanan terhadap anggota, maka diharapkan dapat meningkatkan profesionalitas independensi sebagai pelayanan masyarakat dalam bidang keuangan. Semua itu tentunya tidak terlepas dari sistem informasi yang bersifat relevan, akurat, lengkap dan pastinya sederhana (user friendly).

Dalam pengolahan data transaksi banyak sekali jenis pemrograman untuk pengolahan data yang dapat dipilih menurut kesukaan para calon user (pemakai). Salah satu yang dapat dipilih adalah aplikasi dengan menggunakan Microsoft Visual Basic 2010. Keputusan dalam pemilihan Microsoft Visual Basic 2010 diambil berdasarkan berbagai kelebihan yang dimilikinya yaitu menyediakan perangkat yang dapat digunakan untuk membuat program aplikasi baik aplikasi kecil dan sederhana untuk keperluan sendiri[4].

\section{BAHAN DAN METODE}

Dalam menyusun penelitian ini penulis melakukan beberapa metedologi untuk memperoleh data atau informasi dalam menyelesaikan permasalahan. Adapun metedologi yang dilakukan adalah sebagai berikut [5] :

1. Studi Literatur

Melalui studi ini penulis memperoleh data atau informasi dengan mengumpulkan, mempelajari dan membaca berbagai refensi baik itu dari buku-buku, jurnal, paper, makalah maupun internet. Dan berbagai sumber lainnya yang menunjang dalam penulisan penelitian ini. 
2. Analisis data

Menganalisis pencatatan data nasabah pada sistem yang dibangun.

3. Perancangan dan Pengujian sistem

Merancang aplikasi sistem informasi dengan menggunakan Visual Basic 2010 dan database acess 2007, kemudian melakukan pegujian terhadap aplikasi yang dibangun.

\subsection{Pengertian Sistem}

Istilah sistem berasal dari bahasa Yunani yaitu "sistema", ditinjau dari sudut katanya suatu sistem dapat diartikan sebagai kumpulan atau himpunan dari unsur, komponen atau variabel-variabel terorganisir, saling tergantung satu sama lain dan terpadu yang berfungsi untuk mencapai tujuan[4]. Sistem adalah kumpulan-kumpulan elemen yang saling berkaitan dan bertanggung jawab memproses masukan (input) sehingga menghasilkan keluaran (output)", yang prosesnya berupa proses fisik, proses konseptual, proses prosedural, proses sosial[6]. Sistem adalah suatu kesatuan yang terdiri dari dua atau lebih komponen atau subsistem yang saling berinteraksi untuk mencapai tujuan". Unsur-unsur yang mewakili suatu sistem secara umum adalah masukan, pengolahan,dan keluaran. Masukan meliputi pengumpulan data mentah dari dalam organisasi atau dari lingkungan luar organisasi. Keluaran mentransfer informasi yang telah diproses untuk dapat digunakan pemakai dalam berbagai tujuan. Sistem juga memerlukan suatu umpan balik untuk menghasilkan keluaran yang tepat bagi penggunanya dengan mengevaluasi masukan yang diproses.

\subsection{Pengertian Informasi}

Informasi sebagai jumlah ketidakpastian yang dikurangi ketika sebuah pesan diterima yang artinya dengan adanya informasi, tingkat kepastian menjadi meningkat. Informasi sebagai "data yang telah diproses sedemikian rupa sehingga meningkatkan data tersebut. Berdasarkan definisi diatas disimpulkan bahwa informasi adalah data yang telah diolah menjadi sebuah bentuk yang pasti menggambarkan kejadian (event) yang nyata dan bermanfaat dalam pengambilan keputusan saaat ini dan mendatang.Informasi adalah hal yang sangat penting bagi suatu organisasi, oleh karena itu informasi yang dihasilkan haruslah memiliki kualitas sebagai berikut:

1. Tersedia pada waktu yang tepat (tepat waktu).

2. Tidak mengandung kesalahan (akurat).

3. Menggambarkan keadaan yang sebenarnya (up to date).

4. Sesuai dengan kebutuhan (tepat guna).

\subsection{Pengertian Sistem Informasi}

Dalam beberapa permasalahan sistem informasi selalu dititikberatkan kepada bagaimana dalam menghasilkan sebuah informasi dan saran apa yang harus dilengkapi sebagai pendukung yang handal. Sistem informasi adalah sebuah rangkaian prosedur formal di mana data dikelompokkan, diproses menjadi informasi, dan didistribusikan kepada pemakai. Sistem informasi adalah untuk mengumpulkan, memproses, menyimpan, menganalisis, dan menyebarkan informasi untuk tujuan yang spesifik. Sistem informasi adalah suatu sistem buatan manusia yang secara umum terdiri atas sekumpulan komponen berbasis komputer dan manual yang dibuat untuk menghimpun, menyimpan, dan mengolah data serta menyediakan informasi keluaran kepada para pemakai[7], [8].

Sistem informasi adalah kerangka kerja yangmengkoordinir sumber daya untuk mengubah masukan (input) menjadi keluaran (output) guna mencapai sasaran perusahaan".Dari definisi diatas dapat disimpulkan bahwa sistem informasi adalah kerangka mencakup sejumlah komponen (manusia, komputer, teknologi informasi dan prosedur kerja), ada sesuatu yang diproses dan dimaksudkan untuk mencapai suatu sasaran atau tujuan. Dengan kata lain, sistem informasi merupakan suatu kumpulan dari komponen-komponen dalam perusahaan atau organisasi yang berhubungan dengan proses penciptaan dan pengaliran informasi yang terdiri dari beberapa kegiatan yaitu analisis, perancangan (design), implementasi (implementation), dan pemeliharaan (follow up)[9].

\subsection{Koperasi}

Koperasi adalah suatu kumpulan orang-orang, atau perkumpulan-perkumpulan Koperasi, yang secara sendiri-sendiri tidak mampu memenuhi kepentingan masing-masing. Anggotanya biasanya mempunyai potensi usaha yang terbatas sekali. Karena itulah mereka secara sukarela bersatu untuk mencapai tujuan bersama, yang pada umumnya bersifat ekonomis[2]. Bersama-sama (secara kolektif) didirikan perusahaan. Mereka masing-masing member sumbangan uang untuk pemupukan modal yang diperlukan dalam melaksanakan apa yang menjadi rencana usahanya. Apabila anggota itu kelak menerima bagian dari sisa hasil usaha, maka masingmasing akan memperoleh bagiannya menurut besar kecilnya pelayanan yang diterima dari usaha koperasi.

\subsection{Siklus Pencatatan Akuntansi Koperasi}

Pada prinsipnya system akuntansi Koperasi mengikuti siklus pencatatan akuntansi yang lazim, salah satu diantarannya adalah bagian sebagai berikut: 


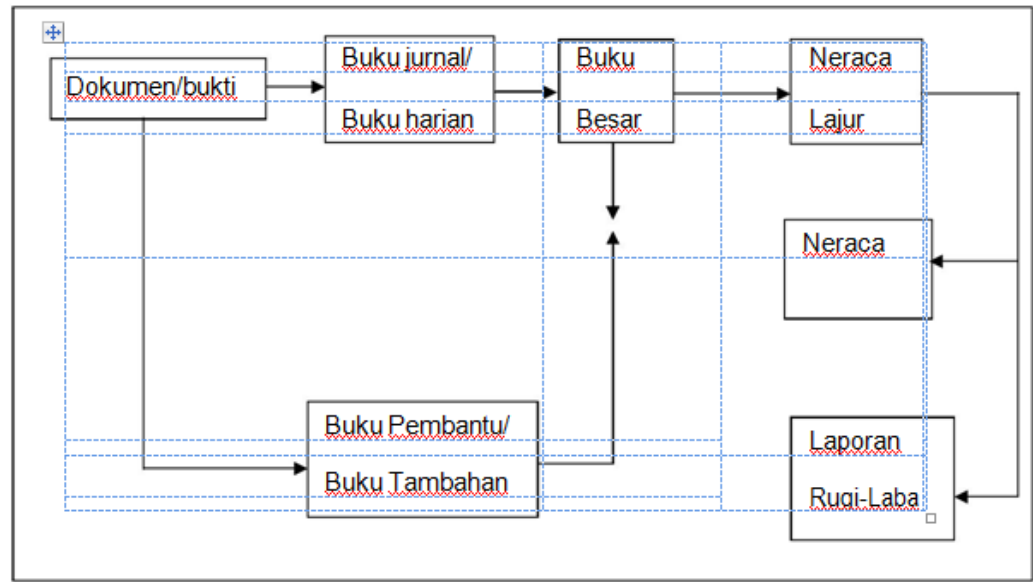

Gambar 1. Alur data Penyimpanan dan Peminjaman

\section{Keterangan bagan}

1. Semua bukti (kwitansi) peyimpanan dan peminjaman dicatat dalam buku harian berdasarkan urutan tanggal kejadian.

2. Semua kejadian yang terekam dalam buku harian itu kemudian secara periodic dikelompokkan dalam buku besar masingmasing.

3. Dan bukti transaksi yang sama dibuat juga buku tambahan, yang fungsinya sebagai pengontrol kebenaran buku besar.

4. Setelah buku besar itu bisa dipasatikan benar, maka saldo yang ada di dalam masing-masing buku besar bisa dipindahkan ke neraca lajur.

\subsection{Laporan Keuangan}

Dalam setiap bisnis (usaha) sekecil apapun satu hal yang sangat penting dalam pengelolaan keuangan ialah membuat laporan keuangan. Laporan keuangan ini dibuat oleh tenaga yang memahami pembukuan atau bahkan seorang akuntan dari dalam koperasi atau koperasi dapat juga meminta bantuan dari akuntan luar berikut analisisnya. Sebenarnya alangkah baiknya bila keahlian akuntan juga dikuasai oleh pengawas. Dengan laporan keuangan ini dapat diketahui penyimpangan-penyimpangan yang terjadi dan memungkinkan bagi semua pihak yang berkepentingan untuk menilai usaha dan keadaan keuangan koperasi secara menyeluruh[1]. Jenis laporan keuangan yang paling banyak digunakan ialah neraca, laporan lugi raba dan laporan perubahan modal, paling tidak neraca dan laporan rugi laba. Keduanya tidak hanya penting bagi pihak internal koperasi tetapi juga untuk pihak lain yang berkepentingan seperti pemerintah, masyarakat, bank dan sebagainya.

\subsection{Neraca (balance sheets)}

Adalah suatu daftar yang berisi ringkasan harta, kewajiban dan modal dari suatub perusahaan (termasuk koperasi) pada saat tertentu. Dengan demikian neraca ini menggambarkan posisi keuangan koperasi pada saat tertentu biasanya pada akhir tahun[3]. Walaupun demikian kemungkinan laporan keuangan ini bisa diminta kapan saja mungkin setiap tri wulan atau tiap akhir semester.Komponenkomponen neraca (balance sheet):

a. Harta/Aktiva/assets:

1. Harta/Aktiva lancar (current assets)

2. Harta/Aktiva tetap (fixed assets)

3. Harta/Aktiva lain

b. Kewajiban/liabilities/hutang seperti Kewajiban/Hutang lancer (jangka pendek), Kewajiban jangka panjang

c. Modal (capital) sendiri seperti Modal dari anggota, SHU yang tidak dibagi

d. Komponen neraca diurutkan dengan ketentuan seperti Aktiva diklasifikasikan menurut ukuran likuiditas (tingkat kecairan), Kewajiban diklasifikasikan menurut urutan jatuh tempo

e. Kewajiban (hutang) seperti Kewajiban lancer (current liabilities): kewajiban yang harus dilunasi dalam jangka waktu maksimal 1 tahun, missal hutang dagang, hutang gaji, hutang pajak, hutang wesel. Dan kewajiban jangka panjang (hutang jangka panjang), yaitu kewajiban/hutang yang harus dilunasi dalam jangka waktu lebih dari 1 tahun. Misalnya hutang obligasi, hipotek, dsb.

f. Modal sendiri seperti Simpanan pokok adalah simpanan yang dibayarkan anggota yang besarnya ditentukan dan dibayar sebagai tanda menjadi anggota koperasi. Simpanan wajib adalah simpanan yang besarnya tertentu (disepakati dalam AD/ART) yang dibayarkan secara rutin kepada koperasi biasanya setiap bulan, Simpanan Sukarela (manasuka) untuk koperasi yang sudah berjalan lama, simpanan ini sering dikategorikan sebagai hutang jangka pendek, karena bisa diambil sewaktu-waktu dan SHU yang tidak dibagikan.

\subsection{Laporan Rugi/laba (income statement)}

Adalah laporan yang berisi ringkasan pendapatan dan biaya dari suatu perusahaan (termasuk koperasi) untuk jangka waktu tertentu misalnya selama 1 tahun, atau 1 semester. Komponen Laporan Rugi/Laba Terdiri atas Penerimaan dan Pengeluaran (beban) yang dikeluarkan koperais pada suatu periode laporan keuangan. Penerimaan, berkaitan dengan kegiatan usaha koperasi[10], alternative 
bentuknya antara lain :

a. Penjualan, bila koperasi menjual produk/barang, missal koperasi konsumsi

b. Hasil jasa, bila koperasi menjual jasa, missal koperasi audit, koperasi transportasi, dsb

c. Hasil sewa, bila koperasi menyewakan barang-barangnya.

\subsection{Analisis Sistem Yang Sedang Berjalan}

Sistem pengolahan data simpan pinjam CU Ate Keleng Sibolangit masih dilakukan secara manual atau masih menggunakan penghitungan excel. Anggota yang melakukan simpanan mengisi sendiri slip penabungan. Anggota yang akan melakukan peminjaman pada koperasi terlebih dahulu mengisi surat permohonan kredit yang sudah disetujui dan ditandatangani oleh panitia kredit, kemudian bagian perkreditan membuat rincian pinjaman.

Dalam pembuatan rincian pinjaman, pegawai masih mencari data anggota dalam buku anggota, untuk mengetahui berapa besar pinjaman yang dapat diterima oleh anggota, sehingga sering terjadi dalam proses pinjaman dan menghabiskan waktu lama. Serta dalam pembuatan laporan masih dilakukan dengan menggunakan Microsoft excel dam word, sehingga masih terdapat kesalahan dalam jumlah dan juga membutuhkan waktu yang lama.

\subsection{Sistem Yang diusulkan}

\section{HASIL DAN PEMBAHASAN}

Adapun gambaran dari sistem yang diusulkan dijelaskan seperti pada diagram berikut.

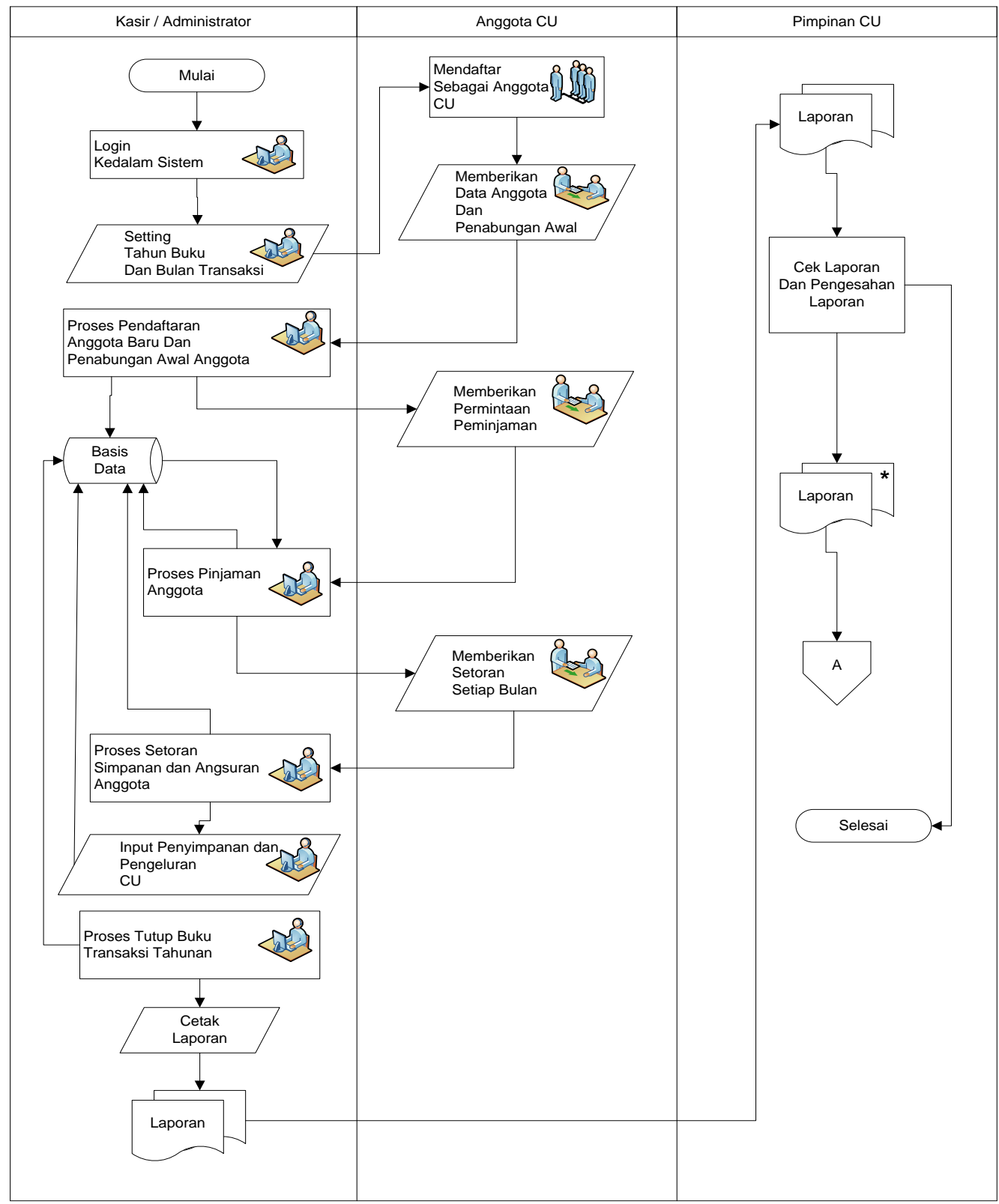

Gambar 2. Alur Data yang diusulkan 
Diagram Konteks, adalah data flow diagram tingkat atas (DFD Top Level), yaitu diagram yang paling tidak detail, dari sebuah sistem informasi yang menggambarkan aliran-aliran data ke dalam dan ke luar sistem dan ke dalam dan ke luar entitas-entitas eksternal. Diagram Konteks menggambarkan sistem dalam satu lingkaran dan hubungan dengan entitas luar. Lingkaran tersebut menggambarkan keseluruhan proses dalam sistem. Secara garis besar diagram konteks Sistem Informasi CU. Ate Keleng Sibolangit dapat dilihat seprti pada Gambar 3

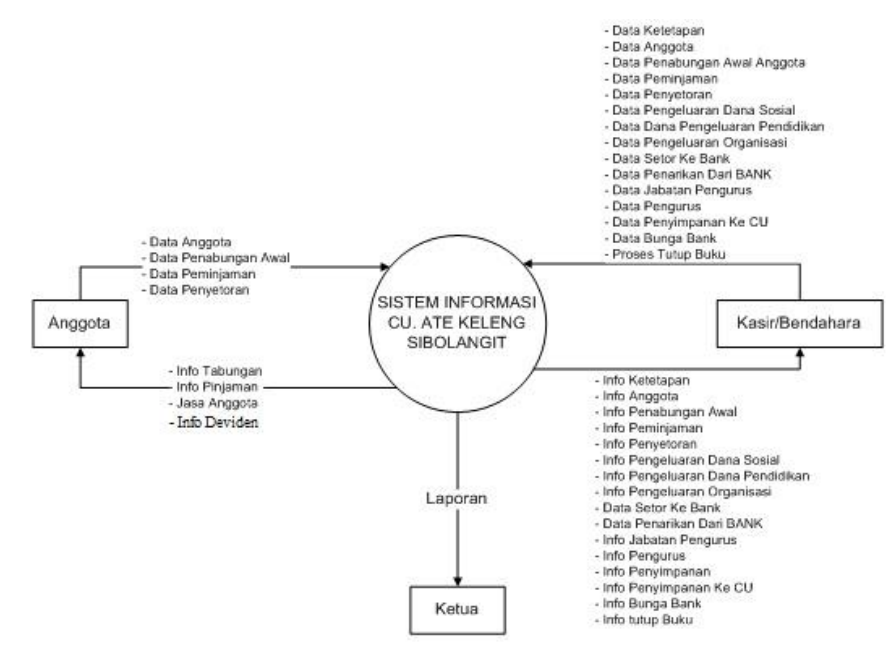

Gambar 3. Diagram Konteks Sistem Informasi CU. Ate Keleng Sibolangit

Sistem Informasi CU. Ate Keleng Sibolangit yang disajikan dalam diagram konteks diatas masih terdapat beberapa proses pencatatan data. Hubungan proses tersebut disajikan dalam diagram arus data level 0, yang diberi penomoran proses. Hubungan antara proses tersebut dapat dilihat pada Gambar 4 


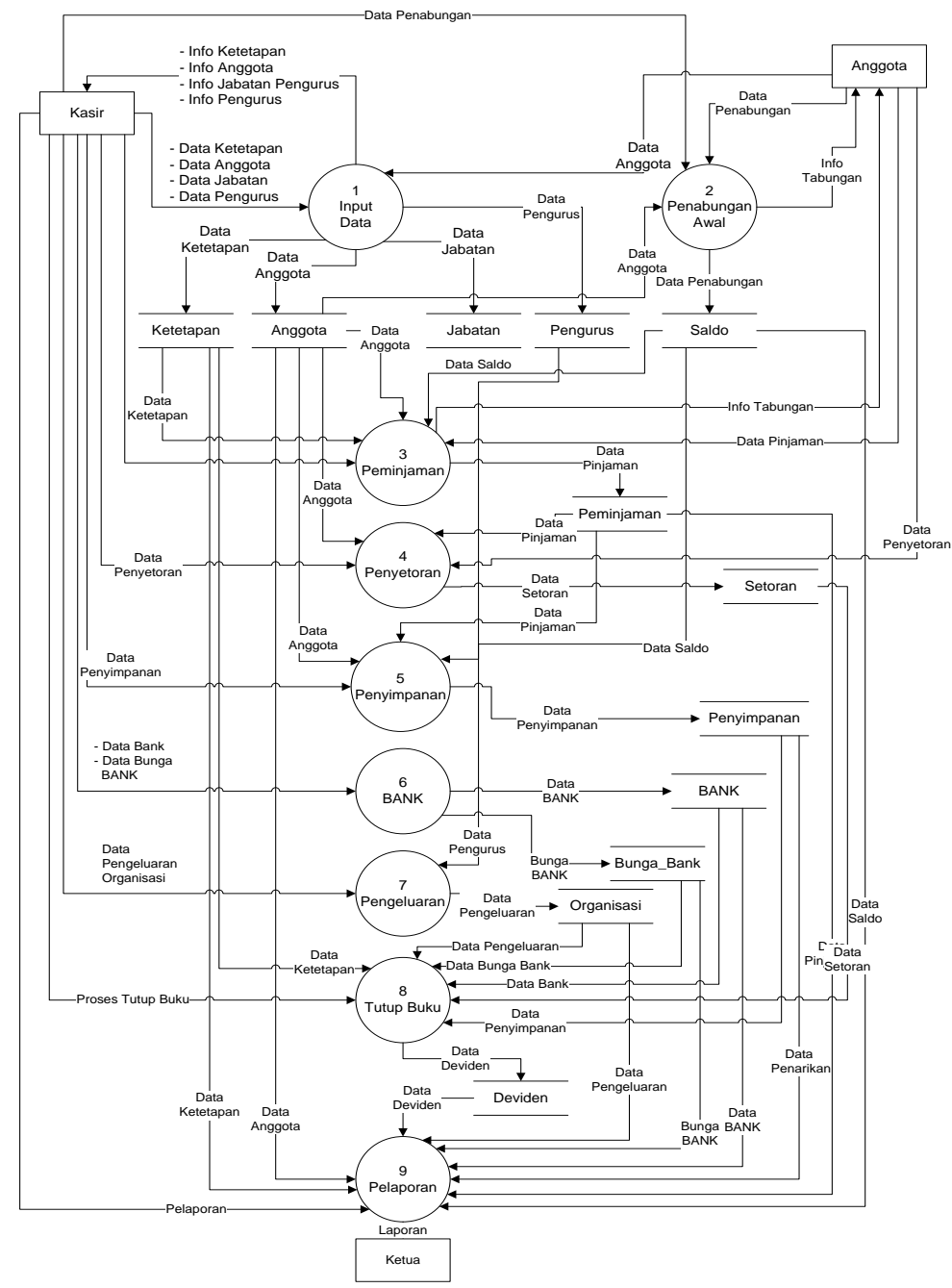

Gambar 4. Data Flow Diagram Level 0

\subsection{Prosedur Mejalankan Sistem Yang Dibangun}

Adapun cara menjalankan atau membuka sistem yang sudah dibangun dijabarkan sebagai berikut.

1. Jalankan aplikasi CU_AteKeleng_Sibolangit.sln yang berada di folder CU_AteKeleng_Sibolangit.

2. Setelah terbuka selanjutnya klIK pada tool bar atau tekan tombol F5 untuk menjalankan sistem

3. Selanjutnya sistem akan meminta username dan password, isikan username dan password, jika benar maka akan masuk ke halaman utama.

Sebelum masuk penentuan bulan transaksi maka pengguna sistem harus melakukan login terlebih dahulu. Tampilan form login dapat dilihat pada Gambar 5.

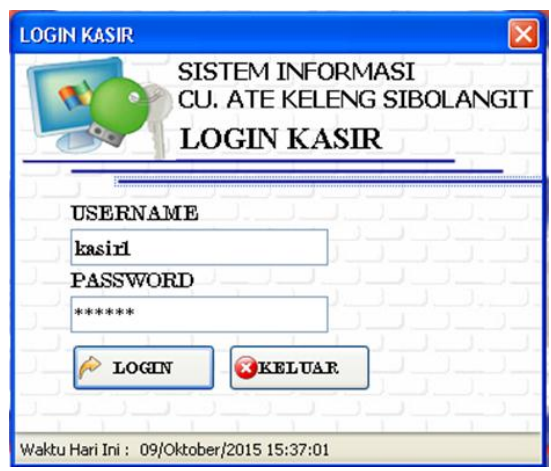

Gambar 5. Form Login

Setelah login berhasil maka pengguna akan diminta menentukan tahun buku dan bulan transaksi. Tampilan seting tahun buku dan bulan transaksi dapat dilihat pada Gambar 6. 


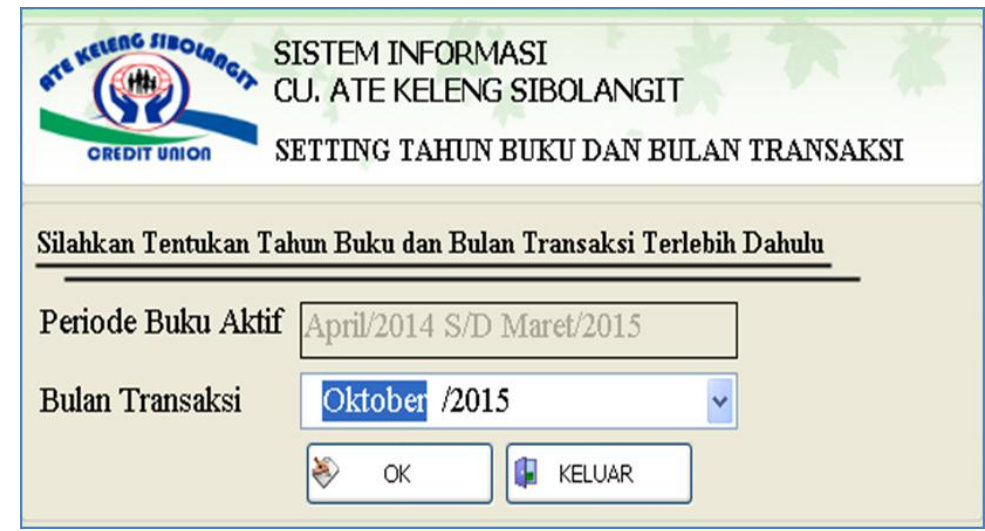

Gambar 6. Form Setting Tahun Buku dan Bulan Transaksi

Sub menu ketetapan berfungsi untuk melakukan pemanggilan form ketetapan. Form ketetapan berfungsi untuk melakukan penginputan data ketetapan CU kedalam tabel ketetapan. Pada form ketetapan terdapat beberapa tombol fungsi yaitu tombol tambah, batal, simpan dan keluar, seperti pada Gambar 7.

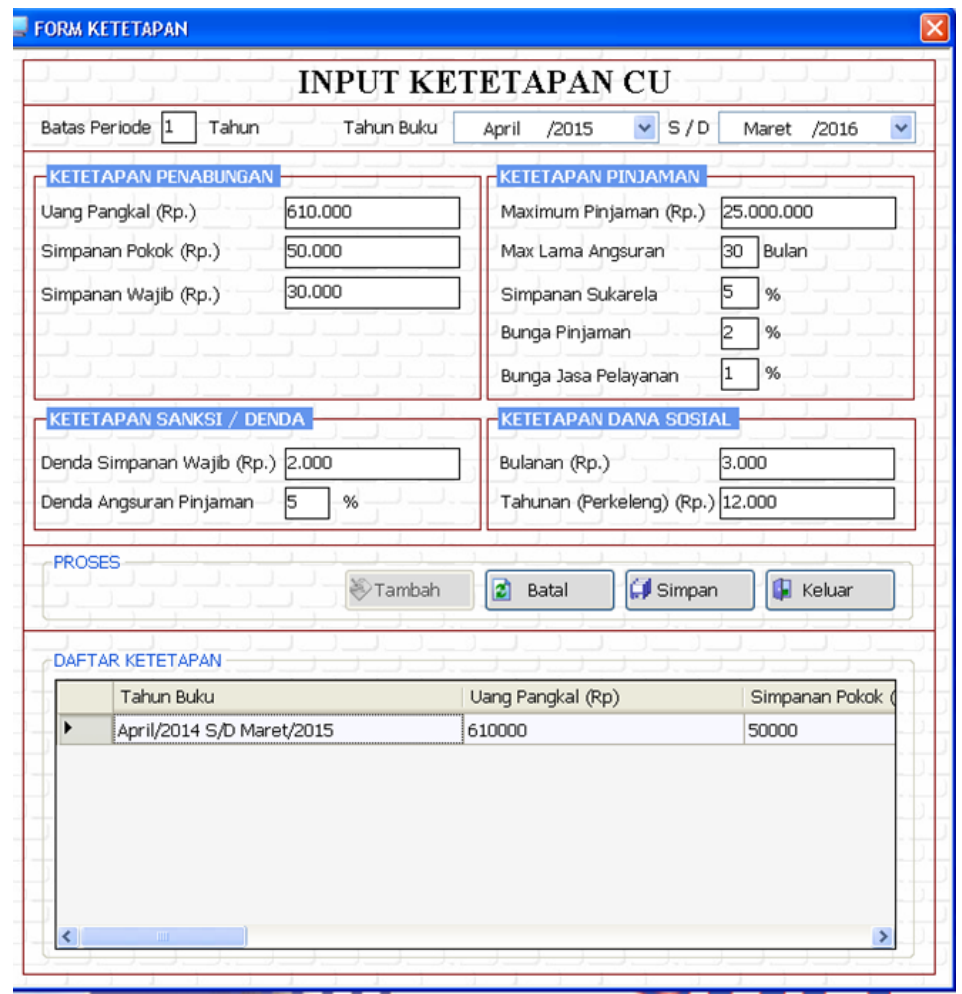

Gambar 7. Form Ketetapan

Sub menu penabungan awal anggota berfungsi untuk melakukan pemanggilan form penabungan awal anggota. Form penabungan awal berfungsi untuk melakukan penginputan data penabungan awal anggota baru pada CU. Ate Keleng Sibolangit kedalam tabel. Pada form penabungan awal anggota beberapa tombol fungsi yaitu tombol tambah, batal, simpan dan keluar, seperti pada Gambar 8. 


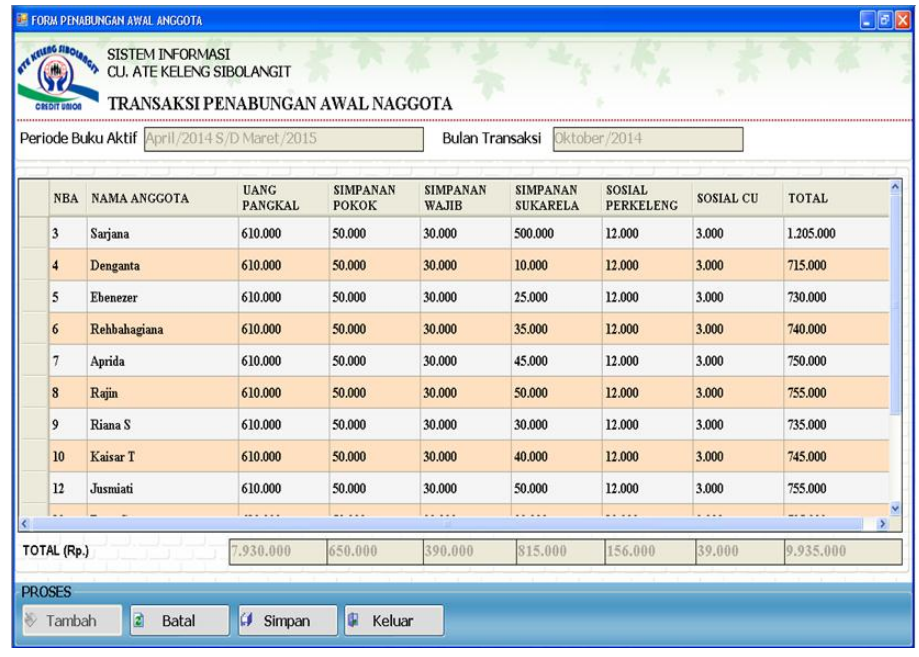

Gambar 8. Form Penabungan Awal Anggota

Sub menu penyetoran berfungsi untuk melakukan pemanggilan form transaksi penyetoran simpanan, penarikan ataupun pinjaman anggota. Form penyetoran berfungsi untuk melakukan penginputan data simpanan wajib, simpanan sukarela, penarikan simpanan, penyetoran angsuran pinjaman kedalam tabel. Form penyetoran dapat dilihat seperti pada Gambar 9.



Gambar 9. Form Transaksi Penyetoran

Sub menu peminjaman berfungsi untuk melakukan pemanggilan form transaksi peminjaman anggota. Form peminjaman berfungsi untuk melakukan penginputan data pinjaman anggota setiap bulan kedalam tabel. Form peminjaman dapat dilihat seperti pada Gambar 10 


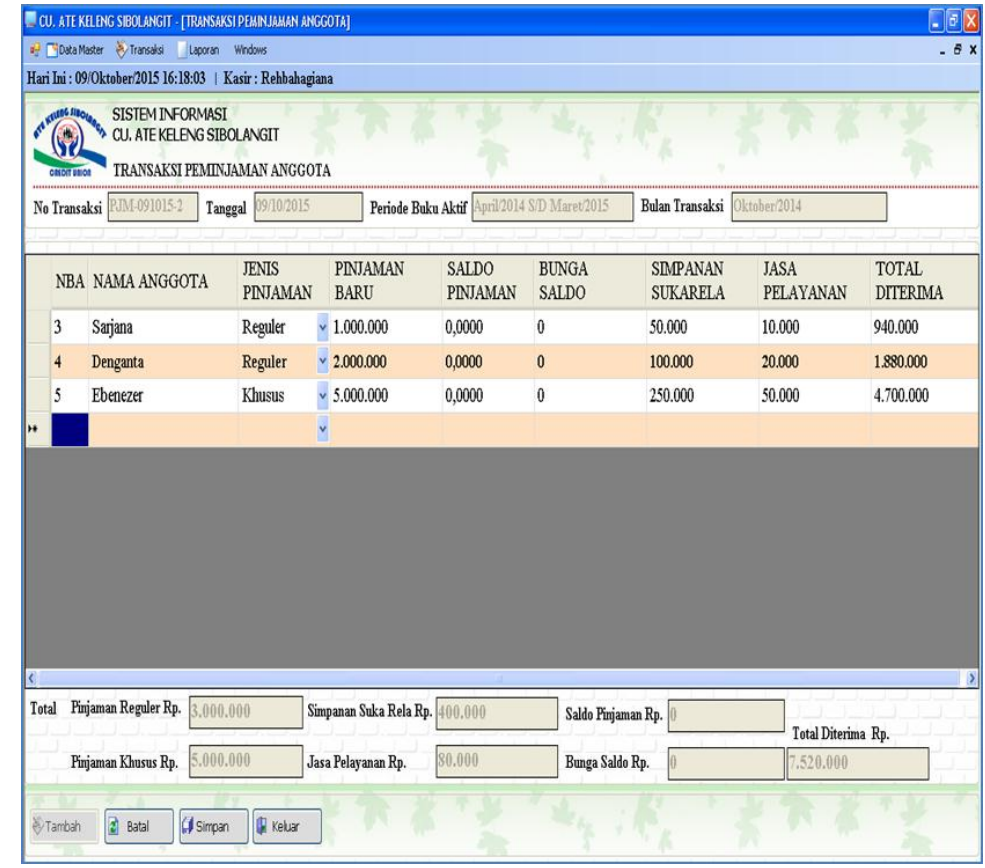

Gambar 10 Form Peminjaman

Sub menu Tutup Buku berfungsi untuk melakukan pemanggilan form tutup buku. Form tutup buku berfungsi untuk menghitung seluruh transaksi uang masukdan uang keluar, laba rugi dan neraca. Form tutup buku dapat dilihat seperti pada Gambar 11 .

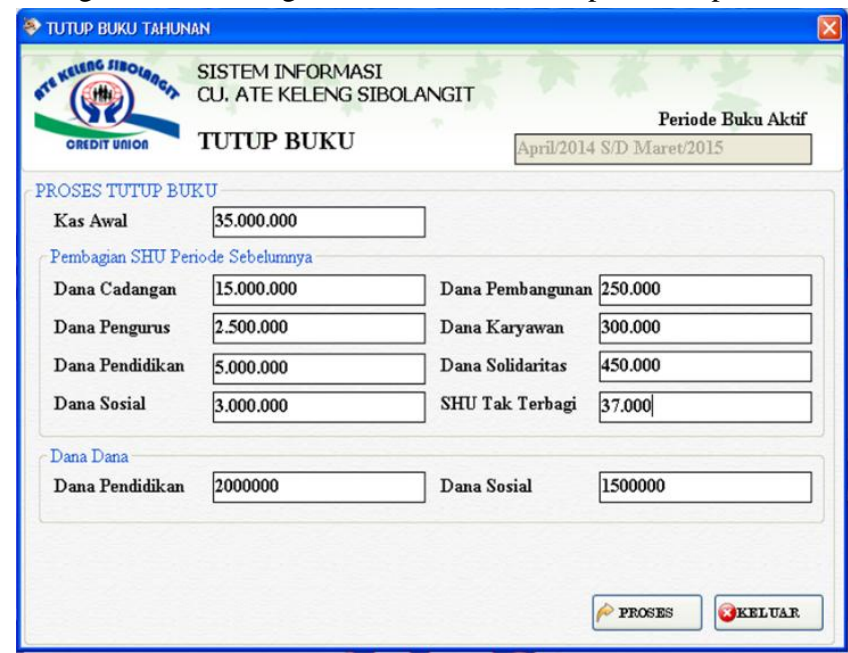

Gambar 11. Form Tutup Buku

Output daftar deviden anggota merupakan salah satu hasil sistem yang dibangun. Dimana daftar deviden anggota berfungsi untuk menyajikan informasi seluruh daftar prolehan deviden anggota yang ada pada CU. Ate Keleng Sibolangit. Daftar deviden anggota dapat dilihat seperti pada Gambar 12 


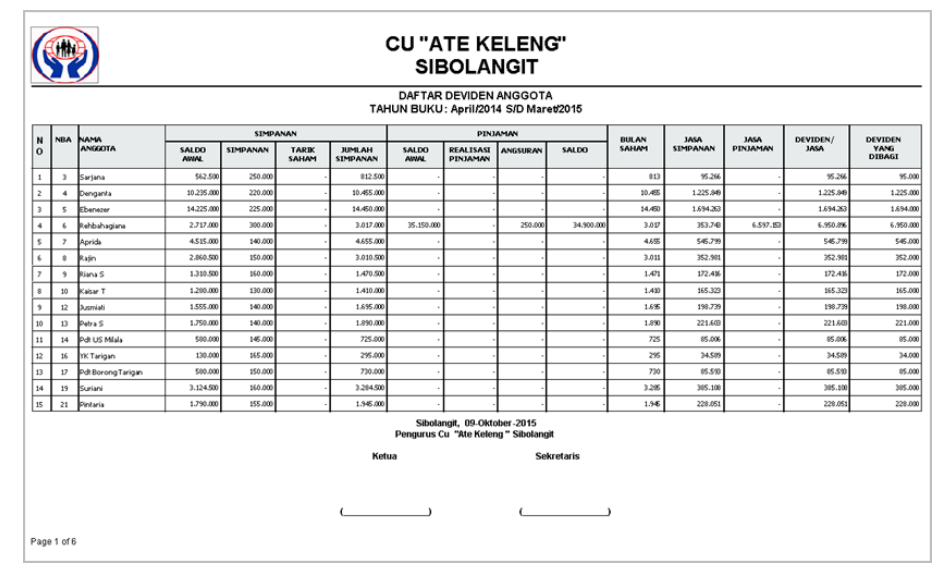

Gambar 12. Daftar Deviden Anggota

Laporan rugi laba perbulan merupakan salah satu hasil sistem yang dibangun. Dimana laporan rugi laba perbulan berfungsi untuk menyajikan informasi seluruh pendapatan dan pengeluaran pada CU. Ate Keleng Sibolangit setiap bulan. Laporan rugi laba dapat dilihat seperti pada Gambar 13

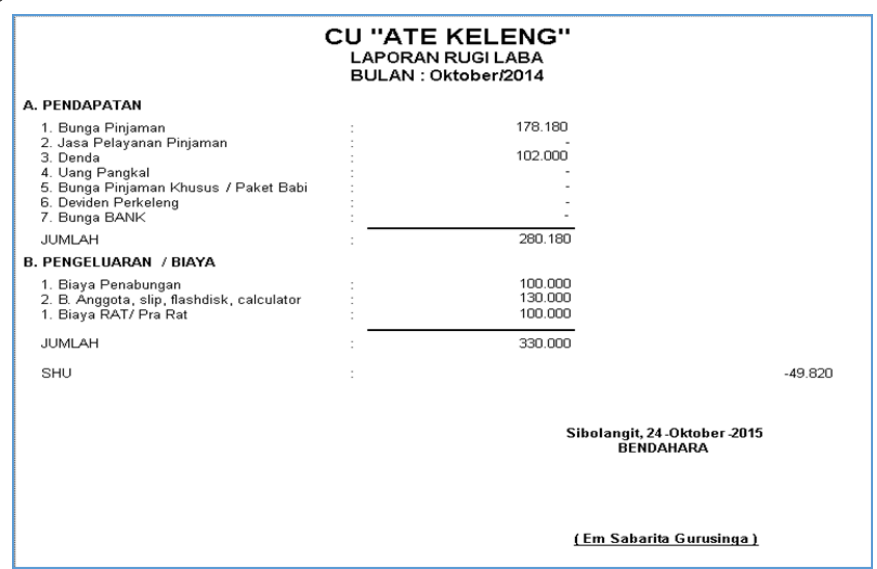

Gambar 13 Laporan Rugi Laba Perbulan

Laporan uang masuk dan uang keluar per-kasir merupakan salah satu hasil sistem yang dibangun. Dimana laporan uang masuk dan uang keluar per-kasir berfungsi untuk menyajikan informasi seluruh uang masuk dan uang keluar pada CU. Ate Keleng Sibolangit setiap tahun. Laporan uang masuk dan uang keluar per-kasir dapat dilihat seperti pada Gambar 14.

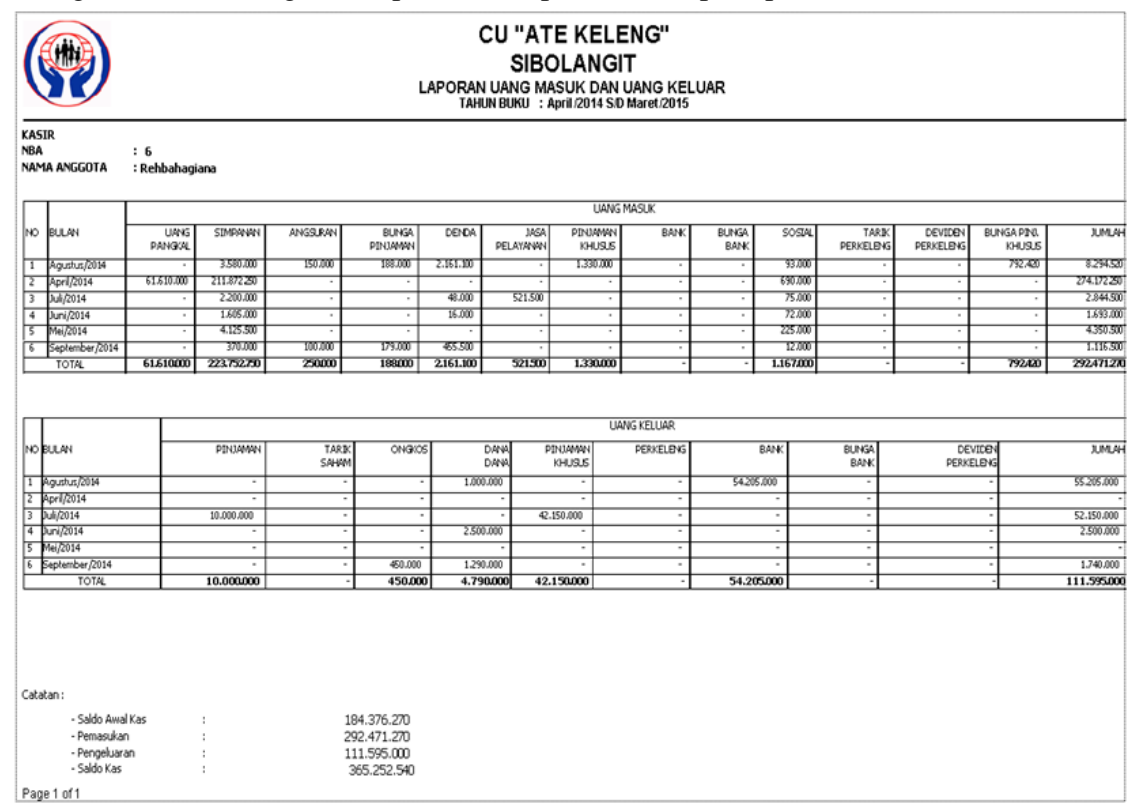

Gambar 14. Laporan Uang Masuk dan Uang Keluar Per-Anggota 


\section{KESIMPULAN DAN SARAN}

Setelah penulis menyelesaikan penulisan ilmiah ini, maka penulis telah mendapatkan banyak hal-hal yang bermanfaat, dengan begitu penulis dapat kesimpulan sebagai berikut :

1. Dengan adanya sistem yang baru maka akan lebih mempercepat cara kerja CU Ate Keleng Sibolangit, karena sistem yang dibangun dapat menangani penabungan awal, penyetoran, dan peminjaman seluruh anggota dalam satu transaksi.

2. Dengan adanya sistem yang dirancang akan lebih mempercepat cara kerja bendahara/kasir, baik dari segi waktu, perhitungan ataupun penanganan transaksi nasabah, karena sistem yang dibangun sudah menggunakan sistem yang multi user.

3. Informasi data yang diperlukan akan lebih cepat didapatkan dan rancangan laporan yang ada pada sistem yang baru lebih baik dari pada sistem sebelumnya.

\section{DAFTAR PUSTAKA}

[1] F. Naeshela, "Peranan Koperasi Simpan Pinjam Credit Union (Cu) Femung Pebaya Cabang Mentarang Di Kecamatan Mentarang Kabupaten Malinau," eJoirnal Pemerintah. Integr., vol. 4, no. 2, pp. 155-165, 2016.

[2] A. Barombo, "Pemberdayaan Masyarakat Melalui Koperasi Credit Union (CU) Studi Pada CU. Khatulistiwa Bakti Pontianak," J. Progr. Stud. Ilmu Sos., vol. 2, no. 0002, pp. 1-17, 2012, [Online]. Available: http://jurnal.untan.ac.id/index.php/jpmis/article/view/960.

[3] H. Widayu, S. Darma, N. Silalahi, and Mesran, "Data Mining Untuk Memprediksi Jenis Transaksi Nasabah Pada Koperasi Simpan Pinjam Dengan Algoritma C4.5," Issn 2548-8368, vol. Vol 1, No, no. June, p. 7, 2017.

[4] H. M. Jogiyanto, Analisis dan Desain (Sistem Informasi Pendekatan Terstruktur Teori dan Praktek Aplikasi Bisnis). Yogyakarta: Penerbit Andi, 2017.

[5] Sugiyono, Metode Penelitian Kuantitatif, Kualitatif dan R\&D. Bandung: PT Alfabet, 2016.

[6] R. H. Malau and T. Limbong, "Sistem Informasi Pemasaran dan Penjualan Hasil Tenun Ulos Desa Lumban Suhi-Suhi," KAKIFIKOM: Kumpulan Artikel Karya Ilmiah Fakultas Ilmu Komputer, 2020. http://ejournal.ust.ac.id/index.php/KAKIFIKOM/article/view/933 (accessed Apr. 20, 2021).

[7] E. S. Sihaloho and W. Ginting, "Sistem Informasi Pemakaman Berbasis Android pada Tempat Pemakaman Umum Kristen Simalingkar B ," KAKIFIKOM: Kumpulan Artikel Karya Ilmiah Fakultas Ilmu Komputer, Oct. 2020. http://ejournal.ust.ac.id/index.php/KAKIFIKOM/article/view/934 (accessed Apr. 20, 2021).

[8] C. M. Saragih and R. Damanik, "Sistem Informasi Penerimaan Pendeta pada Kantor Pusat GKPS Berbasis Web," KakifikomKumpulan Artik. Karya Ilm. Fak. Ilmu Komput., vol. 01, no. 1, pp. 35-39, 2019.

[9] A. Kadir, Pengenalan sistem informasi. Andi, 2003.

[10] I. A. PURNOMO, "Sistem Administrasi Keuangan Sekolah Dengan Menggunakan Java(Studi Kasus: Di SMA Muhammadiyah 4 Andong Boyolali)," 2015. 